\title{
Commentary on Monetary Economics: An Interview with Karl Brunner
}

\begin{abstract}
Professor Karl Brunner is a faculty member at both the University of Rochester, New York, and the University of Bern, Switzerland, and is one of the foremost scholars in the field of monetary theory and policy. He is also a periodic contributor to this Review.

In the following interview, which originally appeared in the July 1978 issue of The Banker, Professor Brunner outlines his interpretation of the monetarist approach to economic analysis in response to comments and questions posed by the publishers of The Banker. The interview is reprinted here because it represents a clear articulation of modern monetarist thought and serves to further the tunderstanding of monetarist policy prescriptions.
\end{abstract}

For many years you have been regarded as one of the leding advocates of a strict "monetary" approach to economic policy. Together with Professor Metzer you have played a leading part th bringing the moneiarist approach to a wider public, both through the Shadow Open Market Commitiee th the United States and in the past wo years in Europe through the Shadow European Economic Policy Committeo (SEEPC). How much progress has been made in persuding pubtic opinion of the merits of monetarism?

Economic policy covers a wide range of measures and the proper role of monetary policy should be clearly recognised. Public opinion occasionally interprets 'monetarism' as a view attributing to money and monetary policy an all-embracing power. This involves a serious misconception. Monetarist analysis essentially emphasises two aspects of the range of policy problems: the relation between monetary growth and the basic rate of inflation, and the relation between monetary acceleration (or unanticipated monetary growth) and temporary changes in output and employment. The first relation determines monetarist propositions about anti-inflationary policies. The second relation determines, on the other hand, proposals bearing on a stable and predictable course of monetary policy. Monetarist analysis implies moreover that monetary manipulation cannot raise the trend of real growth. Neither is monetary expansion a useful device under current circumstances to raise investment expenditures. The falling trend of real growth and investment expenditures is probably dominated by the persistent erosion of the rules of the game' required for a well-functioning market economy. The pervasive uncertainty about economic policy and the gradual attrition of property rights lower real growth and raise the normal level of unemployment. This trend is reinforced by many governmental measures which affect relative wages and prices.

If ofien seems as if public opinion is largely on the side of the monetarists now while public policy continues to be inflationary. How do you explain thas?

I doubt that a major portion of "public opinion" fully accepts the monetarist perspective in matters bearing on monetary policy and monetary events. The English establishment, including the media, cling, with a few exceptions, to the ancient Keynesian story. But let us consider the position of the bureaucracies and officials involved in the formulation and execution of monetary policy. They will find no reason to change their accustomed conceptions and procedures in the absence of serious costs or dangers to their position. The bureaucracies and policy institutions have a strong incentive to persist with their established pattern. The consequence of their misjudgments are usually borne by others. Changes in the conceptions governing an established institution usually require a major crisis, which encourages probing questions and a wide-ranging public debate, combined with a change in the management of the bureaucracy.

How would you sum wh the present siate of the debote?

Indeed, the discussion continues. It continues in scholarly journals and in the arena of public debate. 
But it is important to understand that the nature of the discussion has gradually shifted over the years. Substantial propositions originally advanced by monetarist analysis have been incorporated into professional thinking in the United States. Keynesian analysis still thrives on the other hand, even in archaic forms, in Germany and England. The meshing of ideas occurring between centres of active research has, however, unavoidably shifted the focus of the relevant issues over the past years. Three problems have, in my judgment, emerged from recent debates with a force requiring future attention by scholars. These problems are:

(i) the possibility and usefulness of an activist approach to policy based on optimal control techniques;

(ii) the relative stability of the private and government sector;

(iii) the relevant perspective bearing on the behaviour of the government sector.

A neo-Keynesian position asserts the potential of optimal control techniques and an activist approach to policy-making. The Keynesian tradition also asserts the need for a stabilising government sector to contain or offset the inherent instability of the private sector. Lastly, this tradition reflects a conception of govemment expressed by the 'public interest' or 'goodwill theory of government behaviour. This theory assumes that bureancracies and politicians in general attempt to maximise social welfare. The alternative position rejects this neo-Keynesian perspective. It emphasises, in particular, that optimal control techriques and activism are likely to create instabilities in the economic process. It also stresses the basic stability of the private sector confronting a de-stabilising public sector. This de-stabilisation is linked to an analysis centered on the entrepreneurial behaviour of bureaucracies and politicians. This analysis rejects the 'public interest' theory of govermment frequently used in discussions of stabilisation policy.

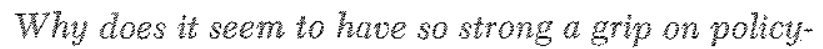
makers? or to put the question in other tems: Why do goverments inflate when there are no benefits to be derived from such action?

Is it really so? We need to look more carefully. The apparent intractability of inflation cannot be explained in tems of the linkages and interactions of the economic process. A radical and sustained reduction of monetary growth below a critical benchmark level determined by a country's institutional environment would effectively remove over time any inflation. The relevant question should thus be addressed to central banks, treasuries and beyond to the nature of the political process shaping the behaviour of these institutions.

Three major channels have unleashed over the past 12 years in various countries excessive rates of monetary growth. One channel works via large and persistent government deficits and corresponding pressures on the central bank to finance the deficit. Italy offers a classic example in this respect. Major groups, including the bureaucracy, find it advantageous to expand the budget. This behaviour is motivated by the wealth transfers produced with the expansion of the budget.

Another channel functions via large and increasing loans made directly or indirectly by central banks to commercial banks. Such loan expansion accelerates the monetary base and ultimately raises monetary growth rates. There emerges under the circumstances an apparently ancontrollable monetary growth. But this uncontrollability essentially results from the central bank's unwillingness, or political inability, to adjust the interest rate charged on central bank accommodation to the realities of the market place. France and Belgium offer some useful illustration in this context. The crucial link in the inflationary process under the circumstances is the political liability burdening the central bank's interest rate policies. And these liabilities reflect again implicit wealth transfers motivating the political constraints.

Lastly, determined efforts to maintain an undervalued exchange rate produce extensive interventions on the foreign exchange markets. These interventions are converted via an acceleration of the monetary base into 'uncontrollable' rates of monetary growth. Maintenance of an undervalued exchange rate involves an abdication of monetary control. Domestic monetary growth is necessarily tied in this case to the inflationary policies of the leading nations. This policy reflects usually, the evident interests of major export industries. It involves again ax implicit transfer of wealth, and it is this which lies behind the political pattern we observe.

So what are the fundamental mistakes made by those whth whom you disagree?

Let us take the OECD as an illustrative example. The OECD vigorously preaches activist financial expansionism as a solution to the major problems of unemployment and low growth. It is caught in old 
conceptions and its bureaucracy seems unable to open a meaningful discussion of newer scientific developments. The measured rates of unemployment and sagging investment expenditures that have been recorded in recent years do not reflect a 'deficient aggregate demand problem' of the nature experienced in the 1930s. The role of supply factors and the effect of institutions and policies on incentives to work and to invest, are basic factors not sufficiently recognised in traditional 'Keynesian' conceptions of the world.

Do you think that price strablity is the only economic oblective a government should have?

Hardly. It is an important objective, but the government's essential function should be to provide a stable and predictable framework for the rules of the social game. This will never satisfy the social activist however. But I urge you to consider that social activism tends to produce institutions which lower our living standards and, ultimately, via a persistent growth of government, endanger our freedom.

Is tit a fundamental assumption of your position thet the real economy is wherenty self-stabilising?

Yes. The Keynesian tradition proceeded on the view that the market system is inherently unstable or prone to settle, whenever left alone, around activity levels substantially below 'potential output'. This perspective, supplemented with the 'public interest theory' of government, explains the activist approach to 'stabilisation policy'. We contend on the other hand that the market system is a shock-absorbing and selfregulating system with built-in stabilising properties. We also contend that the problem can be approached beyond metaphysics and ideology as an issue to be assessed by proper procedures of empirical examination.

A sot wersion of monetarism would allow the awhorities to use fiscal policy in a discretionary manner, to offet swings in the business cycle, whilst insisting that they frnance any budget defich in a non-mflationay way. You, however, believe in balanced budgets. Why?

This kind of 'soft monetarism' offers no adequate solution. It encourages actually the bad patterns inherited from the past. It implicitly assumes that the 'government' attends to the public interest and can be relied upon to adjust the budget according to 'the needs of stabilisation policies'. This seems to be somewhat naive in our judgment. The political process increasingly produces a persistent deficit and larger budgets in the absence of well understood and widely accepted constitutional rules confining the government's fiscal operation. Moreover, a persistent deficit lowers the likelihood of proper monetary control.

It is often said that monetarists are good at loving down the ground-rules for some ultimate state where a monetary rule can be applied, but not at describing how we get there from the present. Is there force in this critismp

None whatsoever. The assertion depends essentially on a tacit constraint imposed on monetarist proposals designed to move the economy towards a non-inflationary growth path. Our opposition claims that no anti-inflationary policies be admitted which lower temporarily employment and output. Such a condition rules out any meaningful anti-inflationary campaign. This is not because we desire lower employment and output. We desire to stabilise the economy around a stable price level and this requires, at this stage, a persistent reduction of monetary growth. This reduction, unfortunately, may produce a temporary decline of employment and output. The likelihood of this result increases with the length, magnitude and variability of the inflationary episode. But the fact remains that there is no other way to control inflation. I should also mention that the Shadow Open Market Committee in the United States and the Shadow European Economic Committee have repeatedly stated the policies required for the transition period.

A new tem has tecenty crept thto the liscussion of economic policy, after 'crowding out'. This ts she wedge'. Could you explan what this is

'The wedge' refers to the widening gap between the cost to the employer of employing a unit of labour and the net wage received by the employee. This wedge affects various aspects of unemployment inaccessible to manipulation by aggregate demand. It is remarkable how frequently govermments, as recently in England and Sweden, cope with labour market or budget problems with measures which increase the size of the wedge and thus intensify labour market problems. An increase in the wedge lowers employment and lengthens the average duration of unemployment.

Another common criticism of monetarism is that it sacrifces all other objectives of policy to that of achleving price stability. For instance, to atain price stability interest rates might have to go to such a 
level as to damage investment. How do you answer that criticism?

The issue is simply this: the social cost of persistent inflation exceeds, in our judgment, the social cost of a once-and-for-all return to a stable price level. Persistent inflation does not proceed in the pleasing fashion of a smooth and fully anticipated path involving fully-adjusted institutions and behaviour. It is an erratic process with large uncertainties generating large variations in real growth and a comparatively high level of normal unemployment. The road leading out of inflation is costly and unpleasant indeed, but the alternative is much worse. And as to interest rates, even politicians learn on occasion that the best way to lower interest rates permanently is to lower the rate of inflation. Of course, the reversal of the inflationary trend induces temporary increases in rates of interest. But acceptance of permanent inflation, in order to prevent a temporary rise in interest rates, is a typical example of the policies responsible for the contemporary mess.

Why have no central banks adopted a fixed monetary pule?

What are a central bank's incentives to do so? The traditional procedures serve in general the established bureaucracies much better. They offer more opportunities for evasive rhetoric. In particular, they permit banks to claim credit for good conditions and allow useful disclaimers of responsibility for bad developments (eg inflation). It is still remarkable to observe, however, that some central banks are approaching a policy of monetary control which need not involve a fixed rule of rigidly constant growth.

Having monetry targets seems in some ways to make it more difficult for a central bank to control the money stock. For instance, when monetary growth overshoots the target, institutions stop buying government debt becaue they anticipate higher wherest rates and the in tur boosts such monetury expansion. What is your answert

This involves two aspects. One bears on the institutions governing the quality of monetary control. Many central banks (France, Belgium, Germany, England and others) proceed under arrangements which substantially lower the likelihood of pursuing effective monetary control. Inappropriate institutions may effectively obstruct any rational monetary management. Central banks frequently disregard this issue and fail to recognise the importance of develop" ing monetary arrangements which raise the degree of monetary control. Control will never be perfect and the question about speculation induced by deviations from the desired growth path continues to attract attention. But such deviations hardly affect securities with longer maturities. Given a credible policy of monetary control, investors will know that short-run errors in monetary growth will approximately wash out over time. Any short-run overshooting of monetary targets will not produce a decline in bond prices under such circumstances. It is even doubtful that very short-term rates would be seriously destabilised. Interest rates seem much more prone to fluctuate in response to policies geared to stabilise interest rates.

Given intemational mobility of canital, an attempt by a single country to control money by raising interest rates may, it is argued, result simply in an inflow of capital which will swell the money supply further. Do not small open economies have to accept the international inflation rate?

Most definitely not. Switzerland has not accepted the prevailing international rate of inflation. A regime of floating exchange rates offers each country an opportunity to determine the monetary base to the last cent in accordance with its wishes. This implies approximate control of monetary growth, irrespective of capital flows induced by relative interest rates or relative movements of exchange rates and interest rates.

Do we have to accept that exchange rates are bound to be volatile?

The volatility of exchange rates simply reflects the uncertainty about the course of financial policy in various countries. Substantial revisions in the markets" evaluation of future policies are immediately impounded into the current exchange rate. A stable and reliable course of financial policies reduces the fluctuations in exchange rates. No degree of intervention can be a substitute for proper financial policies. Intervention undermines monetary control (Germany and Switzerland) and affects exchange rates beyond the shortest horizon only in cases where markets revise (in response to persistent intervention) their expectations of the course of monetary policy.

Nevertheless central batks seem to be intervening on a larger and larger soale in the markets. Why is thes?

Whether the magnitude of intervention increases remains to be seen. To some extent interventions are 
an instrument for controlling the monetary base without operating on domestic credit markets or manipulating advances to banks. But the major force behind the massive intervention is probably concern about the short-run effects on export industries.

Monetarist analysis has recently been applied to many areas beyond its original and continuing con. cern with monetary policy - for instance, to the economics of bureaucracies.

The connection between monetarist analysis and the emerging work on non-market institutions and the political process is the systematic use of proper economic analysis in both fields of research. There is no monetarist analysis of bureaucracy but there is indeed an analysis of bureaucracy. The motivation of this work lies in the increasing range and importance of the phenomenon.

Is this new economic approach going to put the sociologists out of business?
Hardly. More likely is the expanding application and use by sociologists of the analytic framework developed over many decades in economics. This development is visible in political science and also in psychology.

Monetarism has the reputation of being a hard, even heanless doctrine. How would you answer such a charge?

What is more heartless than irresponsible and foolish advice, or false promises? The hard problems do not change under a deceitful rhetoric. We have experienced rising and erratic inflation, increasing 'unemployment' and lower rates of real growth as a result of 'warm-hearted' policies. It is time to penetrate beyond this cloud of verbalism. We cannot expect to cope effectively with difficult problems under an essentially immoral commitment to refuse a hard and honest examination of the nature of the issues. 